\title{
Kyrgyzstan's Relations with International Financial Organizations: Curse or Curve?
}

\author{
Yaşar Sarı (Kyrgyzstan-Turkey Manas University, Kyrgyzstan)
}

\begin{abstract}
Kyrgyzstan since the collapse of Soviet Union went to the transition path and while it is argued that it succeeded at some points, levels or degree. It is certainly that major obstacles to the successful transition are not overcome. First of all it was necessary to get out of Russian dominated economy since it was itself declining. Kyrgyzstan was the first former Soviet republics left Russian ruble zone and accepted its own currency, som in 1993. Moreover, it is also the first former Soviet republics entered to World Trade Organization (WTO) in 1998.

Second, finding new trade partners and external markets was a challenge. Kyrgyz governments wanted to go outside for two reasons: trading with outsiders at time of economic downturn in CIS was rise profitable and trading with outsiders would be a manifestation of their independence and sovereignty.

It is obvious that since the independence Kyrgyzstan still serves as supply of raw material such as Kyrgyzstan's primary budget income is still composed from natural resources (gold export). The Kyrgyz Republic is also classified as a low-income country with high debt vulnerability, due to these characteristics it is eligible to receive a significant level of grant from international financial organization, like World Bank.

In this paper, Kyrgyzstan's relations with the International Financial Organizations will divide three stages: Romantic years in 1990s, Debate on Heavily Indebted Poor Countries (HIPC) Initiative in 2000s, and the last one, after HIPC and Revolution in 2010.
\end{abstract}

JEL Codes: F59, F50, F33

\section{Introduction}

The breakup of the USSR was accompanied by skyrocketing inflation rates, drastically increased unemployment and dropped national/industrial/economical output. When the initial shocks were tamed down, leaders started thinking about prospective. The midterm plans included: the build up of independent fiscal and monetary policies, finding new trade partners, markets, suppliers and commodities.

Kyrgyzstan since the collapse of Soviet Union went to the transition path and while it is argued that it succeeded at some points, levels or degree. It is certainly that major obstacle to the successful transition is not overcome. This obstacle is in the economic nature and represented by lack of entrepreneurship.

First of all it was necessary to get out of Russian dominated economy since it was itself declining. Leaving a ruble zone was a crucial step in that respect which disattached Kyrgyzstan from Russian economic influence a certain point. Kyrgyzstan was the first former Soviet republics left Russian ruble zone and accepted its own currency, som in 1993. Moreover, it is also the first former Soviet republics entered to World Trade Organization (WTO) in 1998.

Second, finding new trade partners and external markets was a challenge. Kyrgyz governments wanted to go outside for two reasons: trading with outsiders at time of economic downturn in CIS was rise profitable and trading with outsiders would be a manifestation of their independence and sovereignty.

It is obvious that since the independence Kyrgyzstan still serves as supply of raw material such as Kyrgyzstan's primary budget income is still composed from natural resources (gold export). The Kyrgyz Republic is also classified as a low-income country with high debt vulnerability, due to these characteristics it is eligible to receive a significant level of grant from international financial organization, like World Bank.

In this paper, Kyrgyzstan's relations with the International Financial Organizations will divide three stages: Romantic years in 1990s, Debate on Heavily Indebted Poor Countries (HIPC) Initiative in 2000s, and the last one, after HIPC and Revolution in 2010.

As the international community moves from the superpower realpolitik structure of the Cold War era into the new millenium, the world order and its economic order are changing. No longer based on a structure of dependency but rather a structure of interdendepency, the New World Order seeks to create globalization through democratic ideologies and more importantly through an economic structure. By creating the International Monetary Fund, the World Bank, and the World Trade Organization, the international community sought to bring this independent structure to fruition. However, the World Bank, the IMF and the Wto are not successful in helping states become interdependent. Instead of helping create newly independent post-Soviet states through loans, these institutions have created dependent, underdeveloped nations. Not only has the IMF, the World Bank and the WTO created underdeveloped nations, but both continue to perpetuate the first and third world structure of the Old World Order. Since these nations are underdeveloped and not producing to their full capacity, they are 
stuck in a cycle of borrowing from which they can never full break free from and develop. Thus, this cycle of borrowing places these nations in a state of imperialism.

\section{International Financial Organizations: International Monetary Fund, World Bank, World Trade Organization}

Entering into a new era, the international community realized the importance of economics when they gathered together in 1944. Having the League of Nations fail at preventing World War II, the international community decided to reconvene and build another international organization. Meeting at Dumbarton Oaks, these nations began to from the infrastructure of the United Nations. Although the structure was similar to that of the League of Nations, the conference at Dumbarton Oaks introduced the idea of the importance of economics in international organizations. When the nations met again in San Francisco they discussed the importance of economics in the UN further. During this conference the Economic and Social Counsel was officially formed and its role was expanded so that it would be an integral part of the UN Charter.

Before the onset of the UN, 44 nations gathered together in Bretton Woods, New Hampshire to discuss global financial policies. Dealing with world depression after World War II, these 44 nations developed two financial institutions-International Monetary Fund and International Bank for Reconstruction and Development (IBRD) or World Bank to deter further global recession. Established in 1944, the IMF original purpose was to regulate the fixed exchange rate (dollar pegged to gold), to appropriate funds to member countries with balance-of-payment deficits (Bennett, 1995, 290). Today, the IMF has added to its role and its members (originally 39, today 187) in the international market. Because there were so many problems with the fixed exchange rate system, the IMF has moved to a more diverse rating system. Today, countries are allowed to determine the value of their currencies. Countries can take one of two measures. The first possibility is to peg their currency to that of another. For example, Kyrgyzstan may set its currency value to that of the US, so when the US dollar goes up, so will the Kyrgyz som too. The other measure is valuing their currency at what the market says their currency is worth; this is called floating. Because of this new freedom that countries have, the IMF had to increase its regulation measures. The IMF now surveys members' exchange policies. Another newly found responsibility of the IMF is to determine whether a country is acting open and reasonably when they set the value of its currency.

Thus, the purpose of the IMF is to promote international monetary cooperation, exchange rate stability, and the expansion of international trade by acting as a lender of last resort when a member country faced an economic crisis. A member country facing a financial crisis has access to the fund's resources and advice. As a country's drawings become larger relative its quotas, it must meet more exacting standards or so called "conditionalities", which typically mean significant changes in economic policies to ensure that the country's domestic and external deficits are drastically lowered or even eliminated. Failure to meet those conditions result in suspension, renegotiation or even cancellation of the program. Quota is a member country's contributions to the IMF, which is usually based on the country's weight in the global economy. Quotas are usually called "Special Drawing Rights" (SDR), which determines country's voting power and borrowing capacity.

Also, created during the Bretton Woods conference, the World Bank (IBRD) was designed handle cases concerning lending funds to members who could not pay their debts. Throughout its operation, the World Bank has created two affiliates to better facilitate its programs of development. These programs are International Finance Corporation (IFC) which 'stimulates private investments in developing nations' and International Development Association (IDA) which is "provide(s) for the special needs of the least-developed countries" (Bennett, 1995, 313). Through these programs the IMF and the World Bank sought to bring economic stability and order into the international community.

\section{The Kyrgyz Case}

Since their independence, Central Asian countries have experienced problems with their economic structure. As they moved from the imperial controls of Soviet Union, Central Asian countries experience political, economic and psychological traumas within their borders; thus causing a stagnation in their human and collective capital. Furthermore, the international and domestic trading markets were at a standstill, making their agricultural goods hard to export and sell. The combination of crises and stagnation placed these Central Asian countries in severe economic hardships. With very little production of capital within these countries, these nations looked externally to help aid in the rebuilding of their economic structures. The primary source of their aid came from loans from the International Financial Organizations. These loans sparked an opening of commercial trade and trade of ideologies. International financial organizations introduced the idea of open and free markets which lead to an increase in imports of foreign goods to especially Kyrgyzstan. Thus, last twenty years, Kyrgyzstan is importing more foreign goods than exporting and selling their own. Kyrgyzstan was being pulled further into the international economy in such a way that strongly condition its economic development. This development was based on dependency on external benefactors to provide the necessary means to continue the nation's economic structure. 
Kyrgyzstan's poverty was not caused by the country's inability to modernize but by the country's inability to handle economic situations since its independence. After its independence, for restructuring its economy and adopting market economy in the early 1990s Kyrgyzstan turned to the international financial organizations, i.e. the IMF and the World Bank, for help. As a result, Kyrgyzstan became dependent upon funds provided by these organizations out of necessity.

After the collapse of the Soviet Union Kyrgyz economy was severely affected resulting loss of its vast market, because around $91 \%$ of Kyrgyz export with the other union republics of the Soviet Union (Trushin and Trushin, 2000, 99). The collapse of factories and state farms, and the disappearance of Kyrgyz's traditional markets in the former Soviet Union, made Kyrgyzstan worse than any other former Soviet Union republics, except war-torn states Tajikistan, Armenia and Azerbaijan in the early 1990s (Gleason, 2003, 65-66).

Kyrgyzstan joined the IMF ON May 8, 1992 and its quota was 64.5 million SDR then became 88.80 million (about $\$ 140$ million, where \$1 approximately equals to 0.62 SDR). Kyrgyzstan has been implementing economic reforms under financial support from the IMF since 1993. From 1993 till 1998 IMF has implemented different Structural Adjustment programs in the country, which were designed to assist the country to adjust and weather crisis. Then in September 1999, the IMF introduced the Poverty Reduction and Growth Trust (PRGT), formerly Poverty Reduction and Growth Facility (PRGF) program for poorest member states, which faced difficulties in economics. Since 1993 IMF has conducted 7 lending arrangements with Kyrgyzstan:

\begin{tabular}{|c|c|c|c|c|c|}
\hline Facility & $\begin{array}{c}\text { Date of } \\
\text { Arrangement }\end{array}$ & $\begin{array}{c}\text { Date of } \\
\text { Expiration or } \\
\text { Cancellation }\end{array}$ & $\begin{array}{c}\text { Amount } \\
\text { Agreed }\end{array}$ & $\begin{array}{c}\text { Amount } \\
\text { Drawn }\end{array}$ & $\begin{array}{c}\text { Amount } \\
\text { Outstanding }\end{array}$ \\
\hline $\begin{array}{c}\text { Extended } \\
\text { Credit Facility }\end{array}$ & Jun 20, 2011 & Jun 19, 2014 & 66,600 & 9,514 & 9,514 \\
\hline $\begin{array}{c}\text { Exogenous } \\
\text { Shock Facility }\end{array}$ & Dec 10, 2008 & Jun 09, 2010 & 66,600 & 33,300 & 33,300 \\
\hline $\begin{array}{c}\text { Extended } \\
\text { Credit Facility }\end{array}$ & Mar 15, 2005 & May 31, 2008 & 17,760 & 17,760 & 17,381 \\
\hline $\begin{array}{c}\text { Extended } \\
\text { Credit Facility }\end{array}$ & Dec 06, 2001 & Mar 14, 2005 & 73,400 & 73,400 & 30,192 \\
\hline $\begin{array}{c}\text { Extended } \\
\text { Credit Facility }\end{array}$ & Jun 26, 1998 & Jul 25, 2001 & 73,380 & 44,690 & 0 \\
\hline $\begin{array}{c}\text { Extended } \\
\text { Credit Facility }\end{array}$ & Jul 20, 1994 & Mar 31, 1998 & 88,150 & 88,150 & 0 \\
\hline $\begin{array}{c}\text { Standby } \\
\text { Arrangement }\end{array}$ & May 12, 1993 & Apr 11, 1994 & 27,090 & 11,610 & 0 \\
\hline \multicolumn{3}{|c|}{ Total } & 412,980 & 278,424 & 90,387 \\
\hline
\end{tabular}

Table 1. Lending Agreements Conducted by the IMF with Kyrgyzstan

The programs are conducted in Kyrgyzstan by the IMF since 1993 include in five spheres. Those five spheres are: fiscal policy (taxes and governmental subsidies), monetary and exchange rate policy (inflation), external sector policies (foreign trade, taxes on imports and exports), debt strategy (balance of payment), structural reforms (banking sector, privatization, energy sector). It is obvious that developing countries, like Kyrgyzstan, might have little choice against "conditionalities" of the IMF. The IMF has expanded its role as "Lender of Last Resort" (Broome, 2010, 50). For that reason, it is understandable then why the IMF and its strategies foist on countries, communities and people to hostile the institution. By providing billions of dollars, or as it is calledlend assistance, the IMF has taken interventions. As the IMF claims that it can improve matter in those countries, which are facing crises, by putting pressure on countries to accept its conditions. In essence, the Fund argues that it must intervene, and quickly, if it determines that an ongoing crisis in one country will spill over to others, that is, the crisis will spread like an infectious disease.

Therefore, the countries, like Kyrgyzstan, who need financial assistance, ask assistance from the international financial institutions. Because the main tool to stabilize economy in these countries, facing economic difficulties, is lends. IMF provides money to adjust balance of payment, reduce poverty, and to overcome other economic problems (Broome, 2010, 125-127). However, money is given under certain conditions, as IMF calls themrecommendations. At a minimum, a loan agreement says the loan goes out on the condition that it will be rapid, usually with the schedule attached. Many loans impose conditions designed to increase the likelihood that they will be repaid. "Conditionality" refers to more forceful conditions, ones that often turn the loan into a policy tool. And often, the IMF keeps up the pretense that the letter of intent comes from the country's government. The IMF, of course, claims that it never dictates but always negotiates the terms of any loan agreement with the borrowing country. But these are one-sided negotiations in which all the power is in the hands of the IMF, largely because many countries seeking IMF help are in desperate need of funds (Stiglitz, 2002, 40). Thus, the 
imbalance of power between the IMF and the "client" country inevitably creates the "client" dependent on the IMF's policies.

The IMF has provided lends and technical assistance by imposing some conditions on Kyrgyzstan. These conditions require Kyrgyzstan to make structural reforms, such as privatization of state-run enterprises, decreasing social programs, and recommendation for political reforms. Some of these conditions violate a recipient country's sovereignty. These "attached conditions" makes the IMF to hold virtual neo-colonial control over developing countries, such as Kyrgyzstan.

Kyrgyzstan's adoption of shock therapy policies in 1990s as well as political crises sparked economic crises that the Kyrgyz government could not handle (Trushin and Trushin, 2000, 91). Another cause of Kyrgyzstan's economic struggles stemmed from the bad judgment on the government's part. As the market declined, the Kyrgyz government began to implement more policies prescribed by the IMF and World Bank, such as opening domestic market to the foreign competitors without any preparation. At the same time, social and political unrests began to permeate in Kyrgyzstan. The government policies also increased corruption in the country.

Seeing that the government had changed its role in the economic realm it did not want to give up this newfound power. Instead of competing corruption in the government and bureaucracy or trying to encourage investments, Kyrgyzstan turned to the IMF for help. This decision would prove to be detrimental to the Kyrgyz economy, as the effects would last well into the $21^{\text {st }}$ century. Including the IMF in economic policies, lead to an increased dependency by the Kyrgyz government to increase their loans form the IMF to fund their social and economic programs. As a result, the IMF and World Bank, as well as EBRD and Asian Development Bank loans and credits became the imprudence of the government and the source of many of the economic problems of Kyrgyzstan. With the already high inflation rate, the low rate of the som, and the now raising foreign deficit, the loans and credits from the international financial institutions only increased the amount of money Kyrgyzstan owed.

Following the IMF prescriptions did not solve the Kyrgyz economic decline. In spite of recovering, Kyrgyzstan continued to get deeper in debt and foreign deficit rose. As a result, to compensate the lowering price of their main export, the Kyrgyz government continued to borrow heavily in the foreign market. This created more problems because it put Kyrgyzstan into deeper debt. Since the government assumed a role that it could not fully facilitate well, hurt the Kyrgyz people and their economy more.

By the 2000s Kyrgyzstan began a frenetic cycle of borrowing. Promising relief from debt burdens, the IMF imposed reforms on borrowers. Much like the Soviet imposed ideologies, these reforms included opening up economies to foreign trade and investment, reducing the role of government, promoting exports, and taking steps against inflation. Through these reforms, the IMF is imposing a new form of imperialism. No longer based on gaining territory, the new imperialism wishes to dominate a country through economic means. By enslaving a country's economic structure, an imperial power can manipulate the country into a state of neo-colonialism. Meaning, these external forces can manipulate countries such as Kyrgyzstan into unequal trading agreements and unfair stipulations to loans. These unequal trading agreements such as a creating a system where only one crash crop may be exported by a country guarantees these nations will continue to be impoverished. Thus, continuing the cycle of borrowing more money.

Not only does this neo-colonialism structure of economic development hinder nations like Kyrgyzstan to form a stable and productive economic structure but it also divides the world again into the haves and the have-nots. The new world order is not based on the first world and third world system anymore, yet with resurgence of imperialism brought upon by the creation of the IMF and the World Bank, this system of division appears to be intact. As mentioned before, nations like Kyrgyzstan are unable to break the cycle of dependence on foreign loans because of historical dependence and governmental decisions. Moreover, they are dependent on these funds because it is the only source of capital entering the country. Therefore, because these nations are unable to grow and develop because of their economic development, they are considered the have-nots. By creating a system of dependence, the world order is still based on the first and third world structure.

The Kyrgyz government took out more and more foreign loans in the 20 years that Askar Akayev and Kurmanbek Bakiyev were in power-selling itself as the "Switzerland of Central Asia" and participating "War on Terror". But those years hadn't produced sustained economic development, and the new government headed by President Roza Otunbayeva has to deal with more sober realities. Total foreign debt is currently put at just over 2 billion 700 million dollars-equivalent to 60 per cent of the country's annual gross national product. Kyrgyzstan has most of debts to the international financial institutions. The largest lenders of Kyrgyzstan are the World Bank, the Asian Development Bank, and the International Monetary Fund that Kyrgyzstan respectively owes 684 million, 608 million, and 175 million dollars. The question as how Kyrgyzstan with its poor economy will pay off its debt arises. This is a serious concern not only of the top officials in the government, but of ordinary people as well; since they are the vulnerable part of the population which is directly or indirectly effected by the decisions of the Kyrgyz government.

There was a chance for Kyrgyzstan to get rid of its debts by joining Highly Indebt Poor Countries (HIPC) 
initiative proposed by the Bretton Wood Institutions (IMF and World Bank). As expected, there was a debate between different political actors whether to join this initiative or not. First group of people said that joining HIPC initiative will mean the loss of face of Kyrgyzstan in front of the international community, since Kyrgyzstan will put on a par with Africa's poorest countries. As a result, it will damage the image of Kyrgyzstan. The second group of people said that there is no chance for Kyrgyzstan to pay off its debts without the aid and support of international financial organizations. At the beginning of this debate both President Kurmanbek Bakiyev and Prime Minister Felik Kulov and Finance Minister Akylbek Japarov agreed to join HIPC Initiative. On March 23, 2006, Prime Minister formally requested a letter to the IMF and the World Bank. In that letter, "we will be happy to welcome any debt reliefs as part of the HIPC, which will help us to solve the problem of debt stability." However, after a long debate on the HIPC initiative in Jonorku Kenesh and Russia's involvement, the Kyrgyz government changed its policy and rejected to participate the initiative on February 20, 2007.

\section{Conclusion}

The IMF and World Bank do not offer assistance but rather they offer dependence and an imperialistic structure. Through the reforms and stipulations placed on these nations, the IMF and World Bank cause states to further indebt themselves. Kyrgyzstan is currently well over 2 billion 700 million dollars in debt. Not only does this debt stem from loans from the Paris Club members but debts from the international financial organizations. The IMF and World Bank were intended to bring economic structure into the international community, but seen by the Kyrgyzstan case, they have only brought economic hardship. The old world order of first and third world nations was to fade with the collapse of communism; however, it is continued with the aid of IMF and World Bank. Through their reforms, the IMF and World Bank have not created economic structure and interdependence but rather economic deterioration and dependence.

\section{References}

- $\quad$ LeRoy A. Bennett, International Organizations: Principles and Issues, Englewood Cliffs: Prentice Hall, 1995.

- Eskender Trushin and Eshref Trushin, "Basic Problems of Market Transition in Central Asia," in Central Asia and the New Global Economy, ed. Boris Rumer, Armonk: M. E. Sharpe, 2000.

- Gregory Gleason, Markets and Politics in Central Asia: Structural Reform and Political Change, London: Routledge, 2003.

- Andre Broome, The Currency of Power: The IMF and Monetary Reform in Central Asia, London: Palgrave Macmillian, 2010.

- Joseph Stiglitz, Globalization and Its Discontents, New York: Norton, 2002.

- IMF, http://www.imf.org/external/about.htm.

- IMF, http://www.imf.org/external/np/exr/facts/sdr.htm.

- IMF, http://www.imf.org/external/pubs/ft/sd/index.asp?decision=11436-(97/10).

- IMF, http://www.imf.org/external/np/fin/tad/extarr2 aspx?memberKey1=565\&date1 key=2011-07-31.

- $\quad 24 . \mathrm{kg}, \mathrm{http}: / / \mathrm{eng} .24 . \mathrm{kg} /$ business/2011/07/29/19459.html.

- IWPR, http://iwpr.net/report-news/kyrgyzstan-grapples-huge-debt.

- $\quad$ Eurasianet.org, http://www.eurasianet.org/departments/insight/articles/eav022307a.shtml. 